\title{
Article/Artigo
}

\section{Diagnosis of hantavirus infection in humans and rodents in Ribeirão Preto, State of São Paulo, Brazil}

\author{
Diagnóstico de infecção por hantavírus em humanos e roedores em Ribeirão Preto, \\ Estado de São Paulo
}

\author{
Glauciane Garcia de Figueiredo ${ }^{1}$, Alessandra Abel Borges ${ }^{2}$, Gelse Mazzoni Campos ${ }^{1}$, Alex Martins Machado \\ Fabiano Pinto Saggioro ${ }^{1}$, Gilberto dos Santos Sabino Júnior ${ }^{1}$, Soraya Jabur Badra ${ }^{1}$, Alberto Anastacio Amarilla Ortiz ${ }^{1}$ \\ and Luiz Tadeu Moraes Figueiredo ${ }^{1}$
}

ABSTRACT

Introduction: Hantavirus pulmonary and cardiovascular syndrome (HPCS) is an emerging serious disease in the Americas. Hantaviruses (Bunyaviridae) are the causative agents of this syndrome and are mainly transmitted through inhalation of aerosols containing the excreta of wild rodents. In the Ribeirão Preto region (state of São Paulo, Brazil), HPCS has been reported since 1998, caused by the Araraquara virus (ARAV), for which Necromys lasiurus is the rodent reservoir. This study aimed to show diagnostic results relating to infection in humans and rodents, obtained at the Virology Research Center of the Ribeirão Preto School of Medicine, University of São Paulo, between 2005 and 2008. Methods: HPCS was diagnosed by means of ELISA and/or RT-PCR in 11 (21.2\%) out of 52 suspected cases, and $54.4 \%$ of these were fatal. Furthermore, 595 wild rodents (Necromys lasiurus, Akodon sp, Calomys tener and Oligoryzomys sp) were caught between 2005 and 2008. Results: Fifteen (2.5\%) of these rodents presented antibodies for hantavirus, as follows: Necromys lasiurus (4\%), Calomys tener (1.9\%) and Akodon sp (1.5\%). Nucleotide sequences obtained through RT-PCR from one HPCS patient and one Calomys tener rodent were compared with hantavirus sequences from GenBank, which showed that both were homologous with ARAV. Conclusions: This work corroborates previous studies showing that ARAV is the hantavirus causing HPCS in the Ribeirão Preto region. It also shows that rodents infected with hantavirus represent a constant risk of transmission of this virus to man.

Key-words: Hantavirus pulmonary syndrome. Araraquara virus. Diagnosis of hantavirus infections. Rodents infected with hantavirus.

\section{RESUMO}

Introdução: A síndrome pulmonar e cardiovascular por hantavírus é uma doença grave emergente nas Américas. Os hantavírus, Bunyaviridae, são os agentes causadores desta síndrome, causadas, principalmente, pela inalação de aerossóis dos dejetos de roedores silvestres. Na região de Ribeirão Preto, a SPCVH, causada pelo vírus Araraquara, tem sido diagnosticada, desde 1998. O roedorreservatório do ARAV é o Necromys lasiurus. Este tem como objetivo mostrar os resultados de diagnósticos da infecção de humanos e roedores obtidos no Centro de Pesquisa em Virologia da Faculdade de Medicina de Ribeirão Preto da Universidade de São Paulo, durante o período de 2005 a 2008. Métodos: A síndrome pulmonar e cardiovascular por hantavírus foi diagnosticada, por ELISA e/ou RT-PCR, em 11 (21,2\%) dos 52 casos suspeitos e destes, 54,4\% foram casos fatais. Além disso, também, de 2005 a 2008, foram capturados 595 roedores silvestres, Necromys lasiurus, Akodon sp, Calomys tener e Oligoryzomys sp. Resultados: Quinze (2,5\%) destes roedores apresentaram anticorpos para hantavírus. As soropositividades intraespécie ou gênero foram $4 \%$ para Necromys lasiurus, 1,9\% para Calomys tener e 1,5\% para Akodon sp. Sequências nucleotídicas, obtidas pela RT-PCR de um paciente com SPCVH e de um roedor Calomys tener, foram comparadas com sequências de hantavírus do GenBank, o que mostrou que ambas tinham homologia com o ARAV. Conclusões: Este trabalho corrobora outros estudos que mostram que o ARAV é o hantavírus causador da SPCVH, na região de Ribeirão Preto, além de mostrar que roedores infectados por hantavírus representam um risco constante de transmissão desses vírus para o homem.

Palavras-chaves: Síndrome pulmonar cardiovascular por hantavírus. Vírus Araraquara. Diagnóstico de infecção por hantavírus. Roedores infectados com hantavírus.

1. Virology Research Center, School of Medicine of the University of São Paulo, Ribeirão Preto, SP, Brazil. 2. Virology and Immunology Research, Biological Sciences and Health Institute, Federal University of Alagoas, Afrânio Jorge, Maceió, AL, Brazil.

Address to: Dr. Luiz Tadeu Moraes Figueiredo. Centro de Pesquisa em Virologia/FMRP/USP. Av. Bandeirantes 3900, 14049-900 Ribeirão Preto, SP, Brasil.

Phone: 55 163602-3271

e-mail: 1tmfigue@fmrp.usp.br

Received in 24/03/2010

Accepted in 28/04/2010

\section{INTRODUCTION}

The genus Hantavirus (family Bunyaviridae) includes three segmented negative-stranded enveloped RNA viruses (100 to 120nm). The large RNA segment (L) encodes the virus polymerase, the medium segment $(\mathrm{M})$ encodes the surface glycoproteins ( $\mathrm{Gn}$ and $\mathrm{Gc}$ ) and the small segment (S) encodes the nucleocapsid protein $(\mathrm{N})$, which is an important viral antigen commonly used for serological diagnoses.

Small mammals, particularly rodents, are the natural reservoirs of hantaviruses. Virus transmission to humans occurs via inhalation of aerosolized urine or excreta, or by direct physical contact with infected rodents. Hantavirus infection in rodent reservoirs usually produces chronic infection with no apparent harm to the animals.

In the Americas, hantavirus pulmonary and cardiovascular syndrome (HPCS) has been recognized since 1993 as an important public health problem ${ }^{1}$. In Brasil, 1,195 HPCS cases were reported between 1993 and 2009, with a 40\% case fatality rate (Brazilian Health Ministry, 2009). Five hantaviruses have been reported to cause HPCS in Brazilian patients: Anajatuba, Araraquara (ARAV), Castelo dos Sonhos (CSV), Juquitiba (JUQV) and Laguna Negra-like.

ARAV is the causative agent for HPCS in the savanna (Cerrado) areas of the central plateau and southeastern Brazil, which includes the Ribeirão Preto region in the State of São Paulo. The natural rodent reservoir for ARAV the Cerrado rodent Necromys lasiurus. Since 1998, 71 HPCS cases have been reported in Ribeirão Preto (Brazilian Health Ministry, 2009). Therefore, ARAV has been considered to be the most virulent hantavirus in Brazil because it produces case fatality more frequently than do other hantaviruses ${ }^{2-4}$. Laboratory diagnosis of hantavirus infection among HPCS patients is important for patient management, and it helps towards acquiring local epidemiologic knowledge on this zoonotic disease in rodents. We show here the laboratory diagnoses of hantavirus infections in humans and rodents that occurred in the Ribeirão Preto region between 2005 and 2008. 


\section{METHODS}

\section{Human samples}

Laboratory diagnoses of hantavirus infection from suspected HPCS cases from Ribeirão Preto and other municipalities in the region were performed on clinical samples at the Virology Research Center (VRC), Ribeirão Preto School of Medicine, University of São Paulo. Between 2005 and 2008, clinical samples from 52 suspected HPCS cases were analyzed at the VRC.

\section{Rodent samples}

Wild rodents were caught by the VRC team in rural areas of the municipalities of Franca, Cajuru and Batatais, between 2005 and 2008. The animals were caught using a single line of 100 Sherman traps, placed at ten-meter intervals, for two to three consecutive nights. The traps were placed at the end of each day and checked the next morning for captured rodents. The captured animals were anesthetized, weighed, sexed and identified based on morphological characteristics ${ }^{5}$. Blood from the animals was collected by means of cardiac puncture or from the retro-orbital plexus. Finally, the rodents were sacrificed and their internal organs (liver, lung, spleen, kidneys and heart) were extracted. All samples were stored, in the field, in a liquid-nitrogen tank. The procedures used for manipulation of the animals followed the best ethical principles on animal research adopted by the Brazilian College of Animal Experimentation.

\section{Serological tests}

Human serum was tested by means of IgM-ELISA and IgGELISA using a recombinant nucleocapsid protein from ARAV as the antigen, as previously reported by Figueiredo et $\mathrm{al}^{6,7}$. The rodent blood was also tested by means of IgG-ELISA using the same technique, but changing to a mixture that included anti-Peromyscus and anti-mouse peroxidase conjugates.

\section{RT-PCR and sequencing amplicons}

RNA was extracted from human blood samples and from lung tissue of humans and rodents using an extraction kit (Qiagen, USA). RT-PCR for genome amplification of $S$ and $M$ fragments of viral RNA segments was performed as previously described ${ }^{8}$. PCR amplicons were identified by size following electrophoresis on agarose gel, and were purified using the QIAquick kit (Qiagen, USA). Direct nucleotide sequencing of amplicons was performed using the $\mathrm{ABI}$ Prism Dye Terminator sequencing kit, and the reaction was run in an ABI Prism ${ }^{\circledast} 100$ Genetic Analyzer (USA).

\section{Nucleotide sequence analyses}

The sequences were analyzed using the Vector NTI software (Informatix, USA) and then aligned with hantavirus $\mathrm{N}$ protein nucleic acid sequences retrieved from GenBank (Table 1) using the Clustal W software ${ }^{9}$. The alignment was edited using the BioEdit software v7.0.0 $0^{10}$ and the phylogenetic relationships among the strains were reconstructed by means of neighbor joining (NJ), using Mega $3.1^{11}$.

\section{GenBank access numbers}

We show here the accession numbers in GenBank for the new sequences from one human sample (GU326299) and one rodent (Calomys tener) sample (GU326298), along with the hantavirus $\mathrm{N}$ protein nucleic acid sequences used in the study:

Alto Paraguay virus (DQ345762); Andes virus (AF291702); Andes virus (AF324902); Andes virus (AF325966); Andes virus (AF482712); Andes virus (AY228237); Andes virus (EU564714); Andes virus (EU564715); Araraquara virus (AF307325); Araraquara virus (EF571895); Araraquara virus (EU170207); Araraquara virus (EU170208); Araraquara virus (EU170209); Araraquara virus (EU170210); Araraquara virus (EU170211); Araraquara virus (EU170212); Araraquara virus (EU170213); Araraquara virus (EU170214); Araraquara virus (EU170215); Araraquara virus (EU170216); Araraquara virus (EU170217); Araraquara virus (EU170218); Araraquara virus (EU170220); Araraquara virus (EU170221); Araraquara virus (EU170222); Araraquara virus (EU170223); Araraquara virus (GU326298); Araraquara virus (GU326299); Bayou virus (L36929); Bermejo virus (AF482713); Calabazo virus (AF395443); Catacamas virus (DQ256126); El Moro Canyon virus (U11427); Hantavirus sp (AF482711); Juquitiba virus (EU373729); Juquitiba virus (EU373731); Juquitibalike virus (DQ345766); Juquitiba-like virus (DQ345765); Laguna Negra virus (AF005727); Lechiguanas virus (AF482714); Lechiguanas virus (EU564713); Limestone Canyon virus (AF307322); Maciel virus (AF482716); Muleshoe virus (U54575); Neembucu virus (DQ345763); Oran virus (AF482715); Paranoa virus (EF576661); Pergamino virus (AF482717); Prospect Hill virus (M34011); Prospect Hill virus (U47136); Puumala virus (AB010731); Puumala virus (AF294652); Rio Mamoré virus (U52136); Seoul virus (AY006465); Sin Nombre virus (L25784); Sin Nombre virus (L37904); Sin Nombre virus (U29210); Sin Nombre virus (U47135).

\section{Ethics}

The wild rodent captures performed as part of this study were authorized by IBAMA (Brazilian Institute for the Environment and Natural Resources), permit number 0115/07 SUPESP/ Fauna/LIC). The study was approved by the Ethics Committee for Animal Research of the Ribeirão Preto School of Medicine (n. 113/2006; May 2007).

\section{RESULTS}

Fifty-two samples from suspected HPCS cases were analyzed by means of RT-PCR and ELISA, and positive diagnoses were made in 11 cases $(21.2 \%)$. Six of these cases were diagnosed using both RTPCR and IgM-ELISA and, in one of them, the ARAV origin was also confirmed by sequencing the RT-PCR amplicon, as shown below. The HPCS diagnosis for four other patients was only confirmed by means of IgM-ELISA. One patient was diagnosed by means of serological conversion in paired serum samples using IgG-ELISA. In this case, the acute-phase serum was negative and the convalescent serum contained IgG antibodies against hantavirus. All these 11 patients were also diagnosed positive for HPCS at the Adolfo Lutz Institute, which is the reference laboratory for hantavirus in the State of São Paulo.

Among the 11 HPCS cases, two occurred in 2006, eight in 2007 and one in 2008. Nine of these patients were male and two were female. One patient was under 20 years of age, nine were between 20 and 40 years old and one was over 40 years of age. Four of these patients were general workers, three were rural workers, two were unemployed, two were housewives and one was a student. Unfortunately, information on rodent contact or activities presenting a risk of hantavirus infection were not obtained. However, one of the patients, a student without contact with rural areas, reported that she became ill immediately after her dog caught the disease and died. All these patients became severely ill and HPCS caused the death of six (54.4\%) of them. 
Among the 52 samples originally analyzed, two of them only had IgG antibodies against hantavirus. Given that they could have had old hantavirus infections, these cases were not diagnosed as HPCS cases.

\section{Rodent samples}

Between 2005 and 2008, 595 wild rodents were caught in the Ribeirão Preto region, as shown in Table 1. Among them, the predominant species was Necromys lasiurus, followed by Akodon sp, Calomys tener and Oligoryzomys sp.

TABLE 1 - Genus/specie of small mammals captured in the field, 2005-2008.

\begin{tabular}{|c|c|c|c|c|c|}
\hline & 2005 & 2006 & 2007 & 2008 & Total \\
\hline Genus/specie & $\mathrm{n}(\%)$ & $\mathrm{n}(\%)$ & $\mathrm{n}(\%)$ & $\mathrm{n}(\%)$ & $\mathrm{n}(\%)$ \\
\hline Akodon sp & $15(11.7)$ & $19(14.0)$ & $57(44.5)$ & $47(23.1)$ & $138(23.2)$ \\
\hline Calomys tener & $25(19.5)$ & $42(30.9)$ & $7(5.5)$ & $33(16.3)$ & $107(18.0)$ \\
\hline Necromys lasiurus & $80(62.5)$ & $61(44.9)$ & $42(32.8)$ & $91(44.8)$ & $274(46.1)$ \\
\hline Mus musculus & $4(3.1)$ & $7(5.1)$ & $1(0.8)$ & $7(3.5)$ & $19(3.2)$ \\
\hline Oligoryzomys $s p$ & $2(1.5)$ & $6(4.4)$ & $18(14.06)$ & $18(8.86)$ & $44(7.4)$ \\
\hline Oryzomys & $0(0.0)$ & $1(0.7)$ & $1(0.78)$ & $3(1.5)$ & $5(0.8)$ \\
\hline Scapteromys sp & $0(0.0)$ & $0(0.0)$ & $0(0.0)$ & $3(1.5)$ & $3(0.5)$ \\
\hline Oxymycterus & $0(0.0)$ & $0(0.0)$ & $2(1.6)$ & $0(0.0)$ & $2(0.3)$ \\
\hline Marsupial (opossum) & $0(0.0)$ & $0(0.0)$ & $0(0.0)$ & $1(0.5)$ & $1(0.2)$ \\
\hline Without identification & $2(1.56)$ & $0(0.0)$ & $0(0.0)$ & $0(0.0)$ & $2(0.3)$ \\
\hline Total & 128 & 136 & 128 & 203 & 595 \\
\hline
\end{tabular}

Samples from these rodents were investigated for hantavirus infection and $15(2.5 \%)$ seropositive animals were detected by means of IgG-ELISA. Among these, the largest number of seropositive findings (nine; $4.4 \%$ ) was among the animals caught in 2008, followed by three (2.3\%) in 2005, two (1.5\%) in 2006 and one (0.8\%) in 2007, as shown in Table 2.

There were six female seropositive rodents and two males, consisting of eight juveniles and seven adults (Table 3 ). The rodents did not present aggression marks. Serum titration was performed on samples from these animals, and 51,200 was shown to be the highest value. This was from a specimen of Necromys lasiurus, as shown in Table 3.

Tissue fragments (blood, heart, kidney, liver and lung) from five of the 15 hantavirus seropositive animals were macerated and RNA was extracted for hantavirus genome detection, by means of RT-PCR. However, it was possible to sequence the hantavirus genome from only one animal, which was a specimen of Calomys tener.

\section{Phylogenetic analysis}

Nucleotide sequences from the $\mathrm{N}$ viral RNA segment of one HPCS patient and one rodent were shown to be ARAV. This was the only virus found in this study, as shown in the phylogenetic tree of Figure 1.

TABLE 2 - Seropositivity to hantavirus of 595 rodents captured in the field, 2005-2008.

\begin{tabular}{|c|c|c|c|c|c|}
\hline & 2005 & 2006 & 2007 & 2008 & Total \\
\hline Genus/Specie & $\begin{array}{c}\text { positives/total } \\
\text { samples }(\%)\end{array}$ & $\begin{array}{c}\text { positives/total } \\
\text { samples (\%) }\end{array}$ & $\begin{array}{c}\text { positives/total } \\
\text { samples (\%) }\end{array}$ & $\begin{array}{c}\text { positives/total } \\
\text { samples (\%) }\end{array}$ & $\begin{array}{c}\text { positives/total } \\
\text { samples (\%) }\end{array}$ \\
\hline Akodon sp & $1 / 15(0.6)$ & $0 / 19(0.0)$ & $0 / 57(0.0)$ & $1 / 47(2.1)$ & $2 / 138(1.5)$ \\
\hline Calomys tener & $1 / 25(4.0)$ & $1 / 42(2.4)$ & $0 / 7(0.0)$ & $0 / 33(0.0)$ & $2 / 107$ (1.9) \\
\hline Necromys lasiurus & $1 / 80(1.2)$ & $1 / 61(1.6)$ & $1 / 42(2.4)$ & $8 / 91(8.8)$ & $11 / 274(4.0)$ \\
\hline Total & $3 / 128(2.3)$ & $2 / 136(1.5)$ & $1 / 128(0.8)$ & $9 / 203(4.4)$ & $15 / 595(2.5)$ \\
\hline
\end{tabular}

TABLE 3 - Data on the hantavirus-seropositive rodents.

\begin{tabular}{lccccc}
\hline Registration number* & Genus/specie & Sex & Age $^{* *}$ & $\begin{array}{c}\text { Serum } \\
\text { titer }\end{array}$ & $\begin{array}{c}\text { Municipality } \\
\text { of capture }\end{array}$ \\
\hline 92 & Akodon sp & male & juvenile & NP*** & Franca \\
96 & Calomys tener & male & adult & NP & Franca \\
98 & Necromys lasiurus & female & juvenile & NP & Franca \\
147 & Calomys tener & male & juvenile & $\geq 3,200$ & Cajuru \\
207 & Necromys lasiurus & female & adult & $\geq 51,200$ & Cajuru \\
351 & Necromys lasiurus & male & juvenile & $\geq 100$ & Batatais \\
423 & Akodon sp & male & juvenile & $\geq 200$ & Cajuru \\
442 & Necromys lasiurus & male & adult & $\geq 800$ & Cajuru \\
465 & Necromys lasiurus & male & juvenile & $\geq 800$ & Cajuru \\
471 & Necromys lasiurus & female & juvenile & $\geq 400$ & Cajuru \\
484 & Necromys lasiurus & male & adult & $\geq 3,200$ & Batatais \\
491 & Necromys lasiurus & female & adult & $\geq 3,200$ & Batatais \\
510 & Necromys lasiurus & female & adult & $\geq 6,400$ & Batatais \\
546 & Necromys lasiurus & female & juvenile & $\geq 1,600$ & Batatais \\
558 & Necromys lasiurus & male & adult & $\geq 6,400$ & Batatais \\
\hline
\end{tabular}

${ }^{*}$ registration number used for identification of samples and carcass, ${ }^{* *}$ presumed age based on animal size and reproductive cycle, ${ }^{* * *}$ test not performed. 


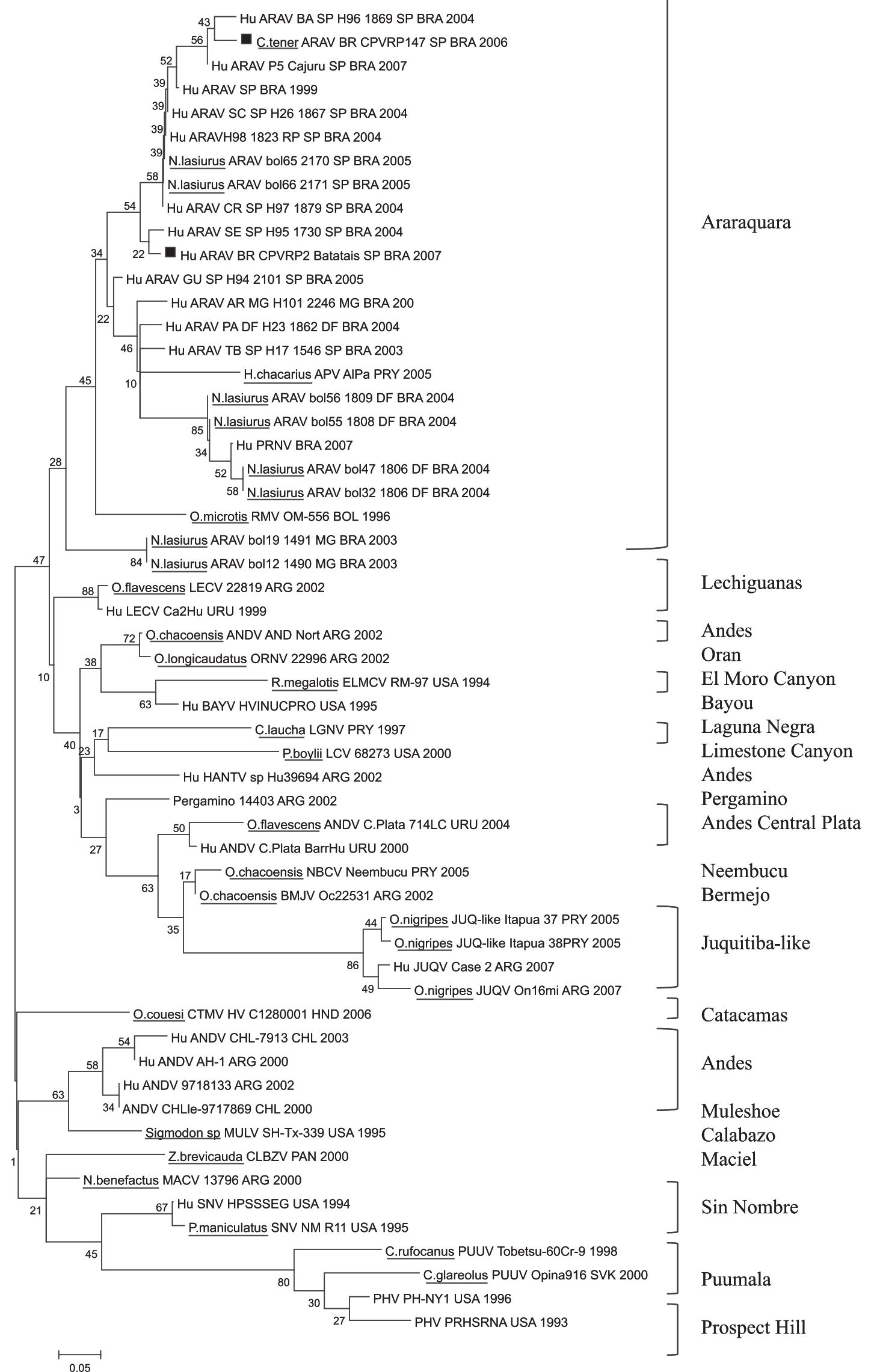

FIGURE 1 - Neighbor-joining phylogenetic tree from 151 nucleotide sequences of the hantavirus N gene from GenBank American hantavirus. The tree includes sequences from one human (GU326299) and one rodent (GU326298) from the present study, marked with a square. 


\section{DISCUSSION}

Brazil is a large country that contains distinct biomes, among which many have already degraded by deforestation, mining and cattle rearing. Sugar cane monoculture, as practiced around Ribeirão Preto, state of São Paulo, can be considered to be a major cause of degradation of the natural biome. Moreover, sugar cane growing has probably banished many wild animal species such as the predators of rodents and, contrarily, it has concentrated and brought closer to man some opportunistic rodents such as Necromys lasiurus ${ }^{12}$.

Since 1998, following the first HPCS cases that occurred in the Ribeirão Preto region, hantavirus diagnostic methods have been developed in the VRC of Ribeirão Preto School of Medicine. These include RT-PCR for hantavirus genome detection in clinical samples and ELISA using $\mathrm{N}$ recombinant protein from ARAV for use as the antigen in serological diagnostic tests for such infections ${ }^{6-8}$. These diagnostic techniques have been useful for diagnosing HPCS among patients in this region ${ }^{13}$. In the present study, 11 patients were diagnosed as having HPCS by using these techniques. These patients were mostly young adult men working in rural or urban low-income manual activities. Their contact with rodents carrying hantavirus infection probably occurred during these activities. The characteristics of these patients and their living conditions were very similar to those reported by other authors in Brazil and also in other countries in the Americas. In a previous study in the Ribeirão Preto region, 70 HPCS cases were diagnosed, among which $75.7 \%$ were men of mean age 35.8 years ${ }^{14}$. In the state of São Paulo between 1993 and 2007, 78\% of the HPCS cases occurred among males, at a mean age of 31 years, and more than half of the cases were among rural workers ${ }^{15}$. In the present study, we observed a higher number of HPCS cases in 2007 than in 2008. This may have been related to the fact that the dry season from May to September 2007 was exceptionally hot and dry. Donalisio et a $\mathrm{a}^{16}$ observed that the rainfall in inland municipalities in the state of São Paulo in 2007 was low. This weather pattern may have brought hungry wild rodent populations closer to humans in rural areas, looking for harvested grains and other kinds of food. It could thus have increased hantavirus transmission from rodents to humans in that year. Katz et a ${ }^{17}$ studied HPCS cases reported between 1993 and 2006 and observed that these were mostly among men involved in rural activities, with mean age of 31 years. Additionally, reports on HPCS patients from the States of Mato Grosso, Goiás, Minas Gerais and Paraná have shown similar characteristics ${ }^{18-21}$. In Argentina, the reports on HPCS patients have mostly been on men aged 20-29 years who were working in rural areas $^{22,23}$. Bogni et al ${ }^{24}$ reported that in Argentina, the disease occurs mostly among men of productive age, with high prevalence among cleaners of houses invaded by rodents. In Canada, from 1989 to 2006, HPCS was mostly reported among men of mean age 41 years ${ }^{25}$.

The diagnosis of HPCS in the present study was made by means of a combination of serological tests (IgM-ELISA and IgG-ELISA) and molecular biology tests (RT-PCR). We believe that this combination of techniques increases both the sensitivity and the specificity of this diagnosis. Moreover, the same positive diagnosis was confirmed by the reference laboratory for all the HPCS patients. However, one fatal case was negative in tests performed at VRC and the diagnosis of HPCS was only confirmed by immunohistochemical analysis on the lung tissue, performed at the Adolfo Lutz Institute. This patient progressed rapidly to death and our supposition is that he probably did not have time to produce enough IgM or IgG antibodies for this to be detectable using ELISA. Nevertheless, we have no explanation for the failure of genome detection using RT-PCR in this patient, since he was supposedly highly viremic. Therefore, this fatal case corroborates a previous study that showed that ARAV was the most virulent of the Brazilian hantaviruses, producing the highest case fatality rate ${ }^{2}$.

In the present study, $54 \%$ of the confirmed cases were diagnosed by means of RT-PCR and these cases were all positive in the IgMELISA test. The diagnosis of HPCS in four other patients was only made by means of ELISA, through detection of specific IgM antibodies in the acute phase or, in one case, IgG antibodies in the convalescence period. It is possible that the higher sensitivity of the ELISA test, compared with RT-PCR, may have been related to poor conservation of clinical samples during transportation to the laboratory, thereby causing degradation of viral RNA. Moreover, some HPCS patients with very low viremia may have been negative in the RT-PCR test.

Two patients were only positive for IgG in the acute phase of the disease. Both were low-income male manual workers, and it was unclear at what time during their lives they had become infected with hantavirus.

Despite the poor epidemiological information, one case stood out. This was a young female who said that she had not visited any rural areas or come into contact with rodents. This patient mentioned that she had become ill after coming into contact with saliva, urine and excrement of her young dog, which was sick and subsequently died. Unfortunately, it was not possible to investigate hantavirus infection in this animal. However, it is known that dogs and cats can bring infected rodents into homes after catching them outside ${ }^{26-28}$. Zeier et al $^{29}$ reported findings of hantavirus IgG antibodies in dogs, cats, hares and deer. The same authors also reported neutralizing antibodies in dogs, cats, pigs and cattle ${ }^{29-35}$. Ferreira ${ }^{36}$ mentioned that domestic animals like cows, lambs, chickens, dogs, cats and pet rodents could become infected by hantavirus, but without a serious risk of contaminate for their owners. In Brazil, there are no studies on hantavirus infection among domestic animals. However, Araujo et $\mathrm{al}^{37}$ detected hantavirus genomes by means of real time RT-PCR in three marsupial specimens (Micoureus paraguayanus, Monodelphis ihering and Didelphis aurita) and two bats (Diphylla ecaudata and Anoura caudifera) from Biritiba Mirim in the State of São Paulo. Thus, hantavirus transmission from rodents to domestic animals and onwards to humans could have occurred in that patient. Further studies are necessary, in order to investigate other species that are susceptible to hantavirus infection, and whether they might transmit the virus to humans.

It is important to emphasize that HPCS is a severe disease in the Ribeirão Preto region, with a 54\% case fatality rate, which is the highest in Brazil. In this region, HPCS is caused by ARAV, which has been cited by Figueiredo et $\mathrm{al}^{2}$ as probably the most virulent hantavirus in the Americas. It is possible that in many of our patients, HPCS was only suspected when they became severely ill, and this negatively affected their survival ${ }^{2,38}$. However, delays in treating HPCS have also been found to occur in other Brazilian regions, with HPCS case fatality rates caused by other hantaviruses that ranged from $44 \%$ in the state of Mato Grosso to $26 \%$ in the state of Santa Catarina ${ }^{18,39}$.

Searching for hantavirus infection in rodents is important for understanding how the virus is transmitted to humans. In the present study, hantavirus infection was detected in $2.5 \%$ of the captured 
rodents. Sousa et $\mathrm{al}^{3}$ studied rodents from the same region, from 2002 to 2005 , and observed a higher seropositivity rate (5.2\%). In other Brazilian regions, seropositivity to hantavirus in rodents has ranged from 3.5\% (in the central-western region; State of Mato Grosso) to $7.8 \%$ (in the southeastern region; State of Rio de Janeiro) ${ }^{40,41}$.

In the present study, the captured rodents were predominantly Necromys lasiurus, followed by Akodon sp and Calomys tener (Table 1). Antibodies against hantavirus were found mostly in Necromys lasiurus, but also in Akodon sp and Calomys tener (Table 2). Necromys lasiurus is considered to be the reservoir for ARAV in our region, based on previous studies by Sousa et $\mathrm{al}^{3}$ and Suzuki et al, in $2004^{4}$, who studied rodents in the Cerrado region. In the States of Espírito Santo and Rio de Janeiro, specimens of Oligorizomys negripis, Necromys lasiurus, Oryzomys sp and Akodon sp that were caught in the Atlantic rain forest were found to be infected with hantavirus ${ }^{41-43}$. In the southern State of Paraná, hantavirus antibodies were found predominantly in Akodon sp and Oligoryzomys. Thus, it is suspected that the reservoir for the Juquitiba virus (i.e. the hantavirus that occurs in that region) is Akodon montensis ${ }^{42}$. In the central-western region, in the state of Mato Grosso, two hantaviruses (Castelo dos Sonhos and Laguna Negra) are known to cause HPCS, and Calomys sp and Oligorizomys $\mathrm{sp}$ are the possible reservoirs ${ }^{40}$. Thus, different hantaviruses cause HPCS in different regions of Brazil, and each of these has a different rodent reservoir.

Among the rodents infected with hantavirus, most of them were juvenile males (Table 3), as also observed by other authors ${ }^{40}$. Juvenile males might become infected by hantavirus more easily than females due to their aggressive behavior of biting each other during disputes relating to territory or females. Scars or ear and tail bites can be seen in these animals ${ }^{44}$. However, in the present study, the infected animals did not show aggression marks. The hantavirus infections in these rodents were probably produced through inhalation of viral particles or licking. Hardestam et $\mathrm{al}^{45}$ observed that hantavirus transmission through saliva among rodents is more common than through inhalation of excreta containing viral particles.

It was possible to amplify hantavirus genome in only five of the 15 seropositive rodents. Additionally, it was possible to perform nucleotide sequencing in only one of these amplicons. This was from a specimen of Calomys tener. It has also been noticed in other studies that only some hantavirus amplicons produce successful direct nucleotide sequencing ${ }^{3,4}$.

Amplicons containing part of the hantavirus $\mathrm{N}$ gene from one HPCS patient and from a specimen of Calomys tener were sequenced, and these nucleotide sequences were confirmed as coming from ARAV, through comparison with hantavirus sequences from the Americas registered in GenBank. These two sequences were highly homologous with those from the $\mathrm{N}$ gene of ARAV. These results confirm previous reports that ARAV is the causative agent for HPCS in the Cerrado landscape of southeastern Brazil and the central plateau of $\mathrm{Brazi}^{2,3}$. A phylogenetic tree based on the $\mathrm{N}$ gene was constructed, showing that the ARAV samples from humans and Calomys tener were located on the same branch of ARAV as in the GenBank sequences.

Calomys tener is a species of Sigmodontinae rodents that has terrestrial habits and lives in different Brazilian landscapes, ranging from the open lands of the Caatinga, Cerrado and Pantanal to the Mata Atlantica (Atlantic rain forest). This species has been found in the States of São Paulo, Minas Gerais, Goiás, Espírito Santo and Bahia.
Infection of Calomys tener with ARAV probably occurred as a consequence of overspill of the virus from Necromys lasiurus ${ }^{2,3}$. However, other rodent species such as Akodon sp have also been found infected with $\mathrm{ARAV}^{2,3,4}$. Recent papers have shown that hantaviruses been in existence for approximately 900 years and that they are probably still undergoing a process of worldwide spreading among rodents ${ }^{46}$. Thus, it is possible that ARAV could infect and adapt to other rodent species living in the Cerrado region.

In summary, this study shows that ARAV remains the only hantavirus causing HPCS in the Ribeirão Preto region. Further studies are necessary in order to better understand the frequency and variety of rodent species that are infected by hantavirus in the Cerrado region.

\section{CONFLICT OF INTEREST}

The authors declare that they have no conflict of interest.

\section{FINANCIAL SUPPORT}

Fundação de Amparo à Pesquisa do Estado de São Paulo (FAPESP).

\section{REFERENCES}

1. Nichol ST, Spiropoulou CF, Morzunov S, Rollin PE, Ksiazek TG, Feldmann H, et al. Genetic identification of a hantavirus associated with an outbreak of acute respiratiry illness. Science 1993; 262:914-917.

2. Figueiredo LTM, Moreli ML, Souza RLM, Borges AA, Figueiredo GG, Machado AM, et al. Distinct hantaviruses causing Pulmonary Syndrome in Central Plateau, Southeastern and Southern Brazil. Emerg Infect Dis 2009; 15:561-567.

3. Sousa RLM, Moreli ML, Borges AA, Campos GM, Livonesi MC, Figueiredo LTM, et al. Natural host relationship and genetic diversity of rodent associated hantaviruses in Southeastern Brazil. Intervirology 2008; 51:299-310.

4. Suzuki A, Bisordi I, Levis S, Garcia J, Pereira LE, Souza RP, et al. Identifying rodent hantavirus reservoirs, Brazil. Emerg Infect Dis 2004; 10:2127-2134.

5. Bonvicino CR, Oliveira JA, D’ Andrea PSD. Guia dos roedores do Brasil, com chaves para gêneros baseadas em caracteres externos. Rio de Janeiro: Centro Pan-Americano de febre Aftosa-OPAS/OMS; 2008

6. Figueiredo LTM, Moreli ML, Borges AA, Figueiredo GG, Souza RLM, Aquino VH. Expression of a hantavirus $\mathrm{N}$ protein and its efficacy as antigen in immune assays. Braz J Med Biol Res 2008; 41:596-599.

7. Figueiredo LT, Moreli ML, Borges AA, de Figueiredo GG, Badra SJ, Bisordi I, et al. Evaluation of an enzyme-linked immunosorbent assay based on Araraquara virus recombinant nucleocapsid protein. Am J Trop Med Hyg 2009; 81:273-276.

8. Moreli LM, Sousa RLM, Figueiredo LTM. Detection of brazilian Hantavirus by reverse transcription polymerase chain reaction ampliacation of $\mathrm{N}$ gene in patients with hantavirus cardiopulmonary syndrome. Mem Inst Oswaldo Cruz 2004; 99:633-638

9. Thompson JD, Gibson TJ, Plewniak F, Jeanmougin F, Higgins DG. The CLUSTAL_X windows interface: flexible strategies for multiple sequence alignment aided by quality analysis tools. Nucleic Acid Res 1997; 25:4876-4882.

10. Hall TA. Bioedit: a user-friendly biological sequence alignment editor and analysis program for Windows 95/98/NT. Nucleic Acids Symp Ser 1999; 41:95-98.

11. Kumar S, Tamura K, Nei M. MEGA 3: Integrated Software for Molecular Evolutionary Genetics analysis and Sequence Alignment. Brief Bioinform 2004; 5:150-163.

12. Mills JN. Regulation of rodent-borne viruses in the natural host: implication for human disease. JN Arch Virol 2005; 19 (suppl):45-57.

13. Campos GM, Borges AA, Badra SB, Figueiredo GG, Souza RLM, Moreli ML, et al. Síndrome pulmonar e cardiovascular por hantavírus: aspectos clínicos 
de uma doença emergente no sudeste brasileiro. Rev Soc Med Trop 2009; 42:282-289.

14. Campos GM. Síndrome Pulmonar e Cardiovascular por Hantavírus: estudos sobre uma doença emergente. Doctor Thesis showed to Clinic Medical Aftergraduation in School of Medicine of the University of São Paulo in Ribeirão Preto; 2007.

15. Katz G, Tengan CH, Kanamura CT, Ferreira IB. Vigilância Epidemiológica de hantavirose no estado de São Paulo, 1993-2007. In: Abstract Book. II Workshop Nacional de Pesquisas Aplicadas em Hantavirus, Cuiabá-MT, Brasil; 2008. p. 59.

16. Donalisio MR, Vasconcelos CH, Pereira LE, Ávila AMH, Katz G. Aspectos climáticos em áreas de transmissão de hantavirose no Estado de São Paulo, Brasil. Cad Saude Publica 2008; 24:1141-1150.

17. Katz G, Tengan CH, Leite RM, Bisordi I, Kanamura CT. Epidemiologic surveillance of hantavirus cardio-pulmonary syndrome in São Paulo State, Brazil, 1993-2006. In: Abstract Book. VII International Conference on HFRS, HPS and Hantaviruses, Buenos Aires, Argentina; 2007.p. 108.

18. Marques AAR, Oliveira EC, Via AVGM, Melo JS. Epidemiologia da hantavirose nos últimos nove anos, Mato Grosso, Brasil. In: Abstract Book. II Workshop Nacional de Pesquisas Aplicadas em Hantavirus, Cuiabá-MT; 2008. p. 15.

19. Neve VCO, Almeida RPAA, Virgínio LF. Situação epidemiológica da hantavirose em Goiás, 2000-2007. In: Abstract Book. II Workshop Nacional de Pesquisas Aplicadas em Hantavirus, Cuiabá-MT; 2008. p. 53.

20. Brito MG, Cortez S, Souza MM, Braga A. Perfil epidemiológico do hantavírus em Minas Gerais, 1998-2006. In: Abstract Book. II Workshop Nacional de Pesquisas Aplicadas em Hantavirus, Cuiabá-MT; 2008. p. 42.

21. Rubio GBG, Gabínio ALPM. Vigilância ambiental e epidemiológica da hantavirose no estado do Paraná, 1992-2008. In: Abstract Book. II Workshop Nacional de Pesquisas Aplicadas em Hantavirus, Cuiabá-MT; 2008. p. 58.

22. Adala R, Galeano F, Corsiglia L. Characterization of HPS patients in a critical care unit. In: Abstract Book, S3-K2. VII International Conference on HFRS, HPS and Hantaviruses, Buenos Aires, Argentina; 2007. p. 42.

23. Marone J, Mariconi L, Agosti MR, Ayala SEG. Hantavirus pulmonary syndrome in La Plata, Argentina. In: Abstract Book. VII International Conference on HFRS, HPS and Hantaviruses, Buenos Aires, Argentina; 2007. p. 18.

24. Bogni L, Benedetti R, Bellomo C, Padula PJ. A ten-year study of hantavirus pulmonary syndrome in Chubut Province, Argentina. In: Abstract Book. VII International Conference on HFRS, HPS and Hantaviruses, Buenos Aires, Argentina; 2007.p. 98.

25. Artsob H, Debrot M, Lindsay R, Safronetz D, Dick D, Feldmann H. Hantavirus pulmonary syndrome in Canada 1989-2006. In: Abstract Book. VII International Conference on HFRS, HPS and Hantaviruses, Buenos Aires, Argentina; 2007. p. 86.

26. Ruo SL, Li YI, Tong Z, Ma QR, Lui ZL, Tang YW, et al. Retrospective and prospective studies of hemorrhagic fever with renal syndrome in rural China. J Infect Dis 1994; 170: 527-534.

27. Simpson SQ. Hantavirus pulmonary syndrome. Heart \& Lung 1998; 27: 51-57.

28. Peters CJ. HPS in the Americas. In: Scheld WM, Craig WA, Hughes JM, editors. Emerging Infections 2, Washington DC: ASM Press; 1998. p. 17-64.

29. Zeier M, Handermann M, Bahr U, Rensch B, Müller S, Kehm R, et al. New Ecological Aspects of Hantavirus Infection: A Change of A Paradigmand a Challenge of Prevention. Virus Genes 2005; 30:157-180.

30. Malecki TM, Jillson GP, Thilsted JP, Elrod J, Torres-Martinez N, Hjelle B. Serologic survey for hantavirus infection in domestic animals and coyotes from New Mexico and northeastern Arizona. J Am Vet Med Assoc 1998; 212:970-973.

31. Willians ES, Yuill T, Artois M, Fischer J, Haigh SA. Emerging infectious diseases in wildlife. Rev Sci Tech 2002; 21:139-157.

32. Nowotny N, Weissenboeck H, Aberle S, Hinterdorfer F. Hantavirus infection in the domestic cat. JAMA 1994; 272:1100-1101.

33. Stallknecht DE, Blue JL, Rollor EA III, Nettles VF, Davidson WR, Pearson JE. Precipitating antibodies to epizootic hemorrhagic disease and bluetongue viruses in white-tailed deer in the southeastern United States. J Wild Dis 1991; 27:238-247.

34. Pejcoch M, Danes L, Zahradkova S, Pekna E. Prevalence of hantavirus infection in small mammals in the South Moravian Region. Cesk Epidemiol Mikrobiol Immunol 1992; 41:92-100.
35. Danes L, Pejcoch M, Bukovjan K, Veleba J, Halackova M. Antibodies against hantaviruses in game and domestic oxen in the Czech Republic. Cesk Epidemiol Mikrobiol Immunol 1992; 41:15-18.

36. Ferreira MS. Hantaviruses. Review. Rev Soc Bras Med Trop 2003; 361:81-96.

37. Araujo J, Henriques DA, Lautenschalager DA, Dutra LMM, Aires CC, Favorito S, et al. Detection of hantavirus by real time PCR in tissues of bats and opossums in the region of Biritiba Mirim, São Paulo. Virus Rev Res 2008; 13: 129.

38. Limongi JE, Costa FC, Paula MBC, Pinto RMC, Oliveira MLA, Pajuaba Neto AA, et al. Síndrome cardiopulmonar por hantavírus no Triângulo Mineiro e alto Paraíba, MG 1998-2005; aspectos clínico-epidemiológicos de 23 casos. Rev Soc Bras Med Trop 2007; 40:295-299.

39. Caldas EP, Predebon J, Brack D, Estima C. Georreferencimento dos casos de hantavirose do Rio Grande do Sul nov1998- abr2008. In: Abstract Book. II Workshop Nacional de Pesquisas Aplicadas em Hantavirus, Cuiabá-MT; 2008. p. 27.

40. Nunes ML, Rosa ELST, D’Andréa PS, Bonvicino CB, Marques AAR, Kohl VA, et al. Dinâmica populacional de roedores silvestres e o grau de infecção por hantavírus na região do Médio Norte do estado do Mato Grosso: dados preliminares. In: Abstract Book. II Workshop Nacional de Pesquisas Aplicadas em Hantavirus, Cuiabá-MT; 2008. p. 12.

41. Sobreira M, Souza GT, Moreli ML, Borges AA, Morais FA, Figueiredo LTM, et al. A serouvey for hantavirus infection in wild rodents from states of Rio de Janeiro and Pernambuco, Brazil. Acta Trop 2008; 107:150-152.

42. Teixeira BR, Pereira LS, Oliveira RC, Stella V, Rúbio GBG, Raboni SM, et al. Caracterização de roedores potencialmente envolvidos na dinâmica de transmissão e manutenção de hantavírus em ciclos silvestres no estado do Paraná. In: Abstract Book. II Workshop Nacional de Pesquisas Aplicadas em Hantavirus, Cuiabá-MT; 2008. p. 9.

43. Bragagnolo C, Lemos ERS, Oliveira RC, Guimarães G, Bonaldo MV, Bonvicino C, et al. Hantavirus em roedores silvestres capturados em uma área não endêmica de síndrome pulmonar por hantavírus no Espírito Santo, Brasil. In II Workshop Nacional de Pesquisas Aplicadas em Hantavirus, Cuiabá-MT; 2008. p. 30.

44. Easterbrook JD, Kaplan JB, Glass GE, Pletnikov MV, Klein SL. Elevated testosterone and reduced 5-HIAA concentrations are associated with wounding and hantavirus infection in male Norway rats. Horm Behav 2007; 52:474-481.

45. Hardestam J, Karlsson M, Falk KI, Olsson G, Klingström J, Lundkvist A. Puumala hantavirus escretion kinetics in bank voles (Myodes glareolus).J Infect Dis 2008; 14:1209-1215.

46. Ramsden C, Melo FL, Figueiredo LTM, Holmes ED, Zanotto PMA, the VGDN Consortium. High Rates of Molecular Evolution in Hantaviruses. Mol Biol Evol 2008, 25:1488-1492. 